\title{
USING LANGUAGE PORTFOLIOS WITH YOUNG LEARNERS TO ENCOURAGE REFLECTION
}

\begin{abstract}
Summary
This paper consists of two parts. The first, introductory part, deals with the theoretical background of using language portfolios for educational purposes and the impact they have on primary school students' language learning. The second part is a small-scale classroom research and it shows how language portfolios contribute to developing learner autonomy and encouraging reflection. It also records the views of teachers on the benefits of portfolio assessment. The results confirm that language portfolios are valuable both for foreign language teachers and for students. Portfolios provide teachers with important information about their students' progress and give insights into students' attitudes to language learning. They are also beneficial for children who learn a foreign language. They enjoy having control of what is included in their portfolios and take pride in their content. The process of collecting pages that would be included in their portfolios encourages children to reflect on the quality of their work from an early age. When they share the content of portfolios with teachers, peers, and parents, they become involved with their learning on a higher level: they think about their learning process, evaluate their work, and identify strengths and weaknesses of their learning strategies. In that way, young learners take charge of their own learning.
\end{abstract}

Keywords: language portfolios, assessment, attitudes, reflection, learner autonomy.

\section{Introduction}

Monitoring students' progress is a vital part of education and teachers use different types of assessment tasks to establish if students are accessing the subject content. In the process of collecting information about students' progress, teachers provide feedback to their students. Bruner stresses that students should be given feedback "not as a reward or punish-

*_omilosevic@isb.rs 
ment, but as information" (Bruner 1961, 26). Although the feedback from teachers is often detailed and with suggestions how to produce better quality work, students often do not use the information they receive to develop study skills and improve their learning. Cruz and Zembo $(2013,40)$ point out that "the use of assessment data has become a part of school culture" and add that although students are assessed "early and often, many do not understand why they are being measured or what useful information assessments provide". This is very unfortunate because thinking and talking about learning is a crucial part of the cycle if the aim is to increase the students' role in their own learning and evaluation of their leaning.

A portfolio represents a collection of an individual student's work that is organized in a file. Norton and Wiburg (cited in Cummins and Davesne 2009,848 ) define portfolio as "a systematic and selective collection of student work that has been assembled to demonstrate the students' motivation, academic growth, and level of achievement". Portfolio assessment consists of two stages. The first stage is collecting the samples. While students make progress in language learning, they make changes in their folder by adding new pieces and removing the ones that are no longer relevant. The second stage of the process is sharing and displaying the portfolio content. Conferences with students help teachers determine what problems their students may have (Murray and Christison 2011). Collecting and organizing samples of work for the portfolio and later, describing its content to the teacher or parents often becomes the starting point for developing independent learners.

The increasing emphasis on learner autonomy demands application of learner-centered approaches to language teaching. In order to become autonomous, students need to be equipped to set their goals, make decisions, evaluate the learning process and develop self-assessment. Little $(2007,15)$ emphasizes the connection between autonomous learners and their language development and states that "development of learner autonomy and the growth of target language proficiency are not only mutually supporting but fully integrated with each other". Cameron (2001, 237) also stresses that connection and points out that "portfolios can link assessment with teaching and with metacognitive development through including pupils in the evaluation of performance". When students inspect 
assessments and activities they want to include in their portfolios, they simultaneously evaluate their work. Little $(2009,6)$ sees the benefits of language portfolios as they help learners "to notice the form in which they are receiving — and giving themselves — feedback, to organize, personalize and interpret it, and to integrate it into the ongoing business of planning and monitoring their learning". Students document what they had learned and start thinking about what they need to change in order to improve their language performance.

Portfolios have great potential to develop reflection. Murphy (1998, 7) maintains that portfolios "invite introspection. They are both receptacles and vehicles for individual reflection". Paulson, Paulson, and Meyer (1991, 61) consider reflection as the one determining characteristic of portfolios, "[t]he collection must include student participation in selecting content, the criteria for selection, the criteria for judging merit, and evidence of self-reflection". Valencia and Paris $(1991,680)$ point out that effective portfolios "involve authentic activities that promote collaborative reflection". By explaining why certain pieces present their work, students use higher order thinking-skills. They need to explain what assessment strategies have been used. In that way they reflect on their involvement in learning and do not concentrate on grades. They identify their strengths and areas for improvement. Theodosiadou and Konstantinidis $(2015,19)$ also stress the role that portfolios play in teaching students to reflect, "portfolios require the students to reflect on their learning which, itself, constitutes a learning exercise". In that way, portfolios are more than collections of personal work, they are recognized as a tool that encourages reflection, feedback, and exchanging ideas.

Portfolio assessment has also been widely accepted as a learning tool when teaching foreign languages to young learners. Iaonnou-Georgiu and Pavlou $(2003,7)$ emphasize the importance of the process of developing knowledge and language skills, and define a language portfolio as "a collection of samples of work produced by a child over a period of time". Although the focus of any language instruction with young learners is on creating opportunities for students to interact and become more engaged with the language, it is equally important to provide child-friendly assessment that would encourage students to develop thinking skills. Pinter $(2006,99)$ 
stresses the importance of "raising children's awareness of various factors that influence their language learning". As students collect their work and choose the samples that are representative of their involvement in class and the learning, they have to consider their learning from different perspectives. The pieces of work that are included in a language portfolio need to be from a range of experiences so that they document the child's language development. When children share their portfolios with teachers, parents, or other students, they consider their successes, identify areas for improvement, and, hopefully, they will begin to set their goals. In this way, portfolios become a tool for reflection as well as a tool for assessment and reporting purposes.

Seitz and Bartholomew $(2008,64)$ point out that portfolio would contribute to the change of student and teacher roles. They explain that "[i] f we, as educators, take the stance that children need to take responsibility for their learning and are partners with us in the classroom, our roles as teachers change and the power shift begins". Students and teachers become collaborators. Students become responsible for their learning and teachers become facilitators of the language acquisition process.

\section{Small-scale Research}

This small-scale classroom-based research was the second part of the teacher research that dealt with different types of assessment in foreign language learning. Language portfolios were introduced in the attempt to develop independent learners and the research explored the benefits of portfolio assessment on student learning.

This research was conducted with seven ten-year-old students who were enrolled in English as an Additional Language (EAL) class and with their two teachers. The goals of this study were to:

a) investigate how language portfolios assist students to self-assess and reflect on their own learning, and

b) understand how teachers promote reflection by incorporating portfolio sessions into class activities.

\section{Context}


The research was conducted in an international school in Serbia where English is the language of instruction. The school enrolls both Serbian and non-Serbian children whose parents currently work in the country. Although there are a number of native English speakers, the majority of students learn English as a second language, and attend additional English classes at some point in their schooling. Students at this school generally stay for two years in the English as an Additional Language (EAL) program. Since the language of instruction is English, every classroom becomes a language classroom.

The research was carried out over the period of approximately eight months. One teacher taught four students and the other teachers taught three students. Those students were placed in EAL class because they needed English support. They had classes five times a week. The students had different language backgrounds and were from five different countries. All of them were very much aware how important English was for them and wanted to master the language as soon as possible. Although their need was a motivational aspect, it also placed a lot of pressure on them. Students needed to use the language but were aware how much more they need to learn. In order to improve their language proficiency, students had to work on developing study skills and they had to be able to plan their learning process, set goals, and evaluate their learning. To encourage students to reflect on their own learning, teachers introduced language portfolios and conferencing as compulsory part of the course.

At the beginning of the school year, each student was given a manila folder and asked to write his or her name and the name of the course on it. They were also encouraged to decorate the folders. Throughout the year, the students were expected to collect samples of their work. At the end of each month they were asked to go through the folder and decide on pieces that showed their learning. That meant selecting the handouts, short texts or drawings that would represent activities that students completed successfully. Students were also expected to provide examples of activities that still had room for improvement. They were instructed to go through the content of their portfolio and remove the tasks that they would not consider important any longer. As they went through the portfolio, they had to explain and justify their decisions for keeping or removing some pieces of work. After each unit, students discussed their choices with the other students and let their teacher know about the selection process. Some 
students included more material in their portfolios, but in general, each portfolio contained fifteen to twenty pieces of work. Students usually excluded grammar worksheets and vocabulary lists explaining that they had practiced and mastered the grammar structures and new words. Teachers often asked questions and the students' answers helped teachers to monitor the way students reflected on their learning. At the end of each term, students had a conference with the teacher, during which they talked about the samples they kept in the portfolio and explained why they considered them as successes or what challenges they had during the assignment.

\section{Data collection and analysis}

Data were collected through lesson observations, conferences with students, students' reflective tasks and interviews with their language teachers. Approximately five hours of class time were recorded, five hours of student-teacher conferences and two hours of interviews with the teachers. The relevant sections of the recordings were transcribed. Lesson observations and conferences with students provided opportunities to gather evidence of student learning and reflection through spontaneous exchanges.

\section{Observations}

Once a unit was completed, students were asked to choose the samples for their portfolio while the teachers observed students making decisions. The teachers took notes and in some cases, filled in checklists. The teachers recorded the choices students made and encouraged them to share the reasons with their classmates. They also captured details of studentstudent interactions (for example, if students could not make decisions easily, or if they were not happy with the quality of their work). While observing students, the teachers kept records of interesting comments and suggestions that they were giving to each other.

\section{Student-teacher conferences}

At the end of each quarter, students had conferences with the teacher. During these conferences teachers would ask students about their selec- 
tion. The teachers used the information to monitor the progress and relevant sections of their conferences were used to establish to what extent portfolios promoted learner autonomy and reflection.

\section{Reflective drawing task followed}

by a conference session with students

At the end of the year students were asked to comment on the progress they made during the course. After a careful examination of the content of their portfolio, the students were assigned a reflective task. To help students reflect, they were told to fold a sheet of A4 paper in half. On the first half they were told to draw themselves at the beginning of the year. On the second half they were asked to draw themselves at the end of the school year. Students were told that they needed to think of the best way to show their feelings and to be prepared to explain the situations they drew. The reflective drawing task was the starting point for that conversation. After they completed the drawings, students were asked to explain their drawings to the teachers. The teacher would talk to one student at a time. The conversations were recorded and later transcribed. The childfriendliness of the method helped students express their ideas both visually and verbally and assisted in explaining what helped them to learn and what obstacles they had in the process.

\section{Informal interviews with their EAL teachers}

The two language teachers were interviewed to establish how useful they thought portfolios were for encouraging students to become autonomous learners and to reflect on their own learning.

\section{Findings and discussion}

\section{Making learning visible}

Students had positive attitudes toward their language learning although they were aware of a number of difficulties and challenges in- 
volved in the process. Language portfolios allowed students' learning to become visible. As the students discussed their reflective drawing task with their teacher, they conveyed both their feelings and their learning curve. Student 1 said, ${ }^{2}$ "In August, there are only Italian words and I was quiet. Now, there are English words, and my face is smiling". Student 2 commented on the language he learned, "I now understand the teachers. It makes sense what they are saying". Student 3 mentioned that she had a lot of friends, "I can talk to them". Opportunity to talk about their work was another learning experience for the students. Going through the work with the teacher, all the students told stories about how they learned English. Student 4 complained that she had frequent headaches at the beginning of the school year. She added, with a touch of humor, "it is different now. I speak English without headache". Student 5 shared a story of him teaching his younger brother English words. Although most students acknowledged difficulties that they experienced, their accounts indicate that they understood that they were acquiring English.

Students also talked about the goals they set for themselves, and demonstrated that they were very much aware about strategies that worked for them. When asked why she did not include any written tasks, student 3 explained, "I make a lot of mistakes, but I want to become better". When the teacher asked how she planned to become better, the student explained, "I will write difficult words five times, and then I will know them".

\section{Developing confidence}

Discussions that students had with their classmates and the teacher gave them ideas how to perform better in class. Considering the process that they had undergone, they could easily see that the small steps they had taken would eventually lead them to better performance. It also meant that students would ask clarifying questions when they did not understand the elements of the task. They engaged more often in conversation with the teacher and other students and asked for feedback.

Linguistic self-confidence is considered to be an important factor in early learning of a foreign language (see for example Mihaljevic Dji-

2 Comments are given verbatim. 
gunovic 2009). As the students learned more language and were asked to think about the process itself, although they were occasionally critical of their performance, they would consider the strategies they could employ to become better. Overall, the impression was that students gained confidence through discussing their portfolios. The discussion itself was a valuable learning experience and provided the students with opportunities for language development. Activities also helped students increase their comfort zone and feeling of success.

\section{Students' and teachers'views on language portfolios}

Both the students and the teachers recognized value of language portfolios. Students in general, liked compiling their work and organizing their folders. During student-teacher conferences, teachers asked students what they thought of the whole process and if they would do it the next year. The students' answers show that they did not think about portfolios in terms of their usefulness. It was a tool that they did not use in other classes. They considered it a novelty, something that was interesting but exclusively related to EAL class. Student 2 commented that it was fun. When asked to explain what it was that he found fun he said, "It is good to look into my writing... I like some of the pictures I made. And it is fun to tell others what I wanted to draw". Although this student did not see language benefits, there were others who saw their language development when they looked into their portfolio. Student 3 mentioned that she could see how much more she knew at the end of the school year. Although students were reflecting during the conferences, they themselves could not see that they were doing anything else than describing their work.

From informal conversations with teachers it was attempted to establish if they could see that the seven EAL students were becoming more reflective, independent learners. The teachers definitely saw a number of benefits of language portfolios. They recorded the progress that students made and they noted that the confidence level had increased. Teacher 1 pointed out that students had to think about the samples that they included and then comment on them. "That gives them the reason to go back to the work they had chosen and they often see their progress. Sometimes they 
are very proud of their work and want to talk more about it, and sometimes they just laugh and explain that it represents their beginning stage." Both teachers saw portfolios as a tool that promotes reflection. Teacher 2 explained that students become used to choosing samples. Once they understood that they would select pieces after each unit, they started thinking about what could be included while they are still working on the task. "It motivates them to pay attention to what they do... and gives them the reason to criticize it... or to be proud of it." They also pointed out the students became more confident over the time. Teacher 2 commented, "Students could see their development, and they feel good about it". Teacher 1 appreciated the idea that she could see what it was that her students identified as interesting activities or as tasks that helped them develop their language. She explained, "Some tasks that I considered important, none of my students thought they learned much from them... and the other way round... some activities that I would only describe as fillers, my students described as opportunities to talk about some things that were important, or they qualified them as activities that helped them acquire new vocabulary. Our ideas did not match every time."

Although both teachers could see the benefits of using portfolios, they also stressed that compiling portfolio meant a lot of work. Teacher 1 explained, "There were times when I found it hard to justify time I allowed students to spend on choosing samples". Teacher 2 was reluctant to let her students choose the samples and to allow students to fully participate in decision making. "I found it hard not to step in and tell some of them, 'Listen, this assignment should be included' instead of a drawing that was produced at the end of one warm-up. I wanted to make decisions myself." They also pointed out that a lot of time had to be devoted to giving students feedback. Teacher 2 commented, "I still do not like the idea of conferencing with students during the class time. I do it when I assign a task so that everyone is working on it, and I can devote my time to one student at a time. But still, I am looking for a better way to do it."

\section{Conclusion}

Language portfolios have a holistic component. They provide teach- 
ers with an opportunity to get a clear picture of their students' growth. While going through the stages of portfolio assessment students are required to focus on learning and to demonstrate their reflection about the process. Portfolios encourage students to think about their learning while selecting and later displaying their work. If the process is carefully led, the students focus on their performance by considering what they completed successfully and obtained feedback from their peers and teachers about the language learning aspects that were not so successful. Students have a real life purpose to learn metalanguage as they consider areas for improvement and find appropriate ways to comment on the work of their classmates.

Language portfolio is children-friendly assessment. When students share their portfolios with others, they tell the story of their language development and that usually invites their listeners to ask additional questions and to provide comments. In the process both parties embark on the reflection journey and make their learning visible.

As students develop ownership of the portfolio, they become autonomous learners. This research supports the idea that using language portfolios can contribute to the quality of work of young learners. The selection and justification processes promote reflection. Students use not only language but also critical thinking skills as they reflect on their learning. It helps them improve their linguistic, social, and academic skills.

Language portfolios will have wider use in the classroom only when more teachers become familiar with the benefits of this assessment method. Currently, many teachers have no training and professional experience in using language portfolios in the classroom. The next step would be incorporating pre-service and in-service teacher training sessions that would make teachers familiar with portfolio assessment as a way of documenting students' progress. Since thinking and talking about learning are essential elements of the portfolio process, there is also a challenge to think carefully about how to introduce reflection into classroom so that it becomes integral part of the learning process.

\section{References}

Bruner, Jerome. 1961. "The act of discovery." Harvard Educational Review 31: 21-32. 
Cameron, Lynne. 2001. Teaching Languages to Young Learners. Cambridge: Cambridge University Press.

Cruz, Heather L., and Debby Zambo. 2013. "Student data portfolios give students the power to see their own learning." Middle School Journal 44 (5): 40-47.

Cummins, Patricia W., and Celine Davesne. 2009. "Using electronic portfolios for second language assessment." The Modern Language Journal 93 (1): 848-867.

Ioannou-Georgiou, Sophie, and Pavlos Pavlou. 2003. Assessing Young Learners. Oxford: Oxford University Press.

Little, David. 2007. "Language learner autonomy: Some fundamental considerations revisited." Innovation in Language Learning and Teaching 1 (1): 14-29.

Little, David. 2009. "The European Language Portfolio: where pedagogy and assessment meet." Paper presented at 8th International Seminar on the European Language Portfolio. Graz, September 29 - October 1, 2009. https://rm.coe.int/CoERMPublicCommonSearchServices/ DisplayDCTMContent?documentId=0900001680459fa5.

Mihaljevic Djigunovic, Jelena. 2009. "Individual differences in early language programmes." In The Age Factor and Early Language Learning, edited by Marianne Nikolov, 99-225. Berlin/New York: Mouton de Gruyter.

Murphy, Sandra M. 1998. "Introduction: Reflection: In portfolios and beyond." The Clearing House: A Journal of Educational Strategies, Issues and Ideas 72 (1): 7-9.

Murray, Denise E., and Marry Ann Christison. 2011. What Language Teachers Need to Know. Vol. II: Facilitating Learning. New York: Routledge.

Paulson, Leon F., Pearl R. Paulson, and Carol Meyer. 1991. "What makes a portfolio a portfolio?" Educational Leadership 48 (5): 60-63.

Pinter, Annamaria. 2006. Teaching Young Language Learners. Oxford: Oxford University Press.

Seitz, Hilary, and Carol Bartholomew. 2008. "Powerful portfolios for young children.” Early Childhood Education Journal 36 (1): 63-68. Theodosiadou, Dimitra, and Angelos Konstantinidis. 2015. "Introducing e-portfolio use to primary school pupils: Response, benefits and challenges." Journal of Information Technology Education: Innovations in Practice 14: 17-38. 
Valencia, Sheila W., and Scott G. Paris. 1991. "Assessment: Portfolio assessment for young readers". The Reading Teacher 44 (9): 680-682.

\title{
Olja Milošević
}

\section{KORIŠĆENJE JEZIČKOG PORTFOLIJA NA RANOM UZRASTU RADI PODSTICANJA UČENIKA DA RAZMIŠLJAJU O UČENJA JEZIKA}

\begin{abstract}
Sažetak
Ovaj rad se sastoji iz dva dela. Uvodni deo se bavi teorijskim osnovama upotrebe jezičkog portfolija u obrazovne svrhe i njegovim značajem za decu koja uče strani jezik na ranom uzrastu. Drugi deo je rezultat istraživanja koje pokazuje na koje načine jezički portfolio doprinosi razvijanju autonomije učenika i podstiče decu da razmišljaju o procesu učenja jezika. Beleže se i razmišljanja nastavnika o značaju portfolija u procesu ocenjivanja. Rezultati potvrđuju da je jezički portfolio značajan kako za nastavnike, tako i za učenike. Portfolio nastavniku pruža važne informacije o napredovanju učenika i omogućava mu da stekne uvid u stavove koje deca imaju o učenju jezika. Portfolio je značajan i za decu koja uče strani jezik. Ona vole da donose odluke o tome koje će radove uključiti i ponosna su na sadržaj svoga portfolija. Proces sakupljanja materijala koji će biti uključen u jezički portfolio podstiče decu da razmišljaju o kvalitetu svojih radova. Kada o sadržaju portfolija razgovaraju sa nastavnicima, vršnjacima i roditeljima, deca razmišljaju o procesu učenja jezika, pocenjuju svoj rad, identifikuju dobre i loše strane svojih strategija. Na taj način, deca preuzimaju odgovornost za učenje.
\end{abstract}

Ključne reči: jezički portfolio, ocenjivanje, stavovi, razmišljane o procesu učenja, autonomija učenika. 